\title{
Approaches for Addiction Treatment: The Freedom of Choice Today
}

\author{
David E Mc Cauley* \\ Founder of Oak Valley Foundation, America
}

Submission: July 19, 2017; Published: July 25, 2017

*Corresponding author: David E McCauley, Founder of Oak Valley Foundation, USA, Tel: 862-247-7749; Email: david@oakvalleyfoundation.com

\section{Opinion}

With the freedom of choice today we must look at all approaches for treating the individual. As what must be celebrated is the individual in recovery. With that in mind I would like to talk about the 9 different approaches and let me say I will be just presenting the facts.

\section{Step Model Alcoholics Anonymous}

I will begin with the most common approach the 12-step model a support network for individuals. Most commonly used in inpatient and outpatient settings for treatment of addiction. A program instituted as a means of recovery and not as a form of rehabilitation. Serves as a means of not only knowledge and the problem but also finding the ability within oneself to overcome the problem.

There is a spiritual element of the program as well however the big book emphasizes the word God which is not suitable for all and is overall one of the biggest complaints that I have heard working in the field and my years of recovery. The fact is A/A roots go back to 1933 where it began in the Oxford Group. The Oxford Group a non-denomination movement of first century Christianity. Founded in 1935 the group separated from the church in 1937.

The 12 steps were first published in 1939 in the first edition of Alcoholics Anonymous the big book) and I might add has not changed with the times we live in today. The first step is to acknowledge the problem after that the individual needs to do their own special kind of self-inventory to make changes if they want to improve their life. The cold hard facts are:

i. $\quad 81 \%$ dropout rate in the first month

ii. $5 \%$ start continue for one year

iii. Overall success rate is less than $5 \%$

iv. Many refer to AA as a cult or a cure

John F Kelly associate Professor and Jean Bersin Professor at Harvard University concluded that the 12 step approaches are almost completely ineffective and even harmful. In my opinion it is archaic and antiquated and has not changed for the times we live in today. Today people do not want labels i.e. alcoholic, addict, etc.

\section{Rational recovery}

This philosophy is a crash course on AVRT Stands for Addictive Voice Recognition Technique. This approach is from addiction to recoveryism solely by the 28 flashcards referred to as "Bullets for my Beast." This has evolved slowly since its inception in the mid1980s. Originally patterned after the familiar forms of addiction treatment, recovery group participation, psychological exercises, and discussion brain structures and the physical aspect. Today it stands as a simple expression of will in the context of family values much more focused, streamlined and intuitive pathway out of addiction.

Rational recovery states Addiction is neither a Disease nor caused by one. Addiction is a chemically enhanced stupidity, literally crazed pleasure seeking that result in anti-family, immoral lifestyle. The Disease concept of addiction disguises intoxication as an innocent and presents the reason you drink/ use mysterious compulsion in the need of medical treatment and exempt from common standards of conduct and decency.

Their belief is your brain is not you, but part of your body. You are the owner of your brain, the human spirit, self, identity I that authorizes all voluntary behavior, your addiction. In AVRT- based recovery, you are on your own, without support, no sponsors, no cheering section, no rescuing deity, no brain to interfere for you, nothing but your dread fear of going to the very bad place you fear, at the bottom of the rung, the scrap heap, or the glue factory. In other words, you possess will and have the ability to choose based upon principles of right and wrong. The reason for their abandonment of science, religion, medicine, and psychology quite simply is:
a. They don't work.
b. They blame the family. 
c. They promote the option of gratifying relapses.

d. They divert your attention from intermediate actions that you must take in order to protect yourself and your family from its horrible losses.

They believe when the disease concept becomes part of your addictive voice, you will feel like a victim of circumstances rather than one who is responsible for becoming addicted, for staying addicted, instead of immediately quitting your addiction right now and for good.

\section{Motivational therapy}

First publicized by Miller and Rollnick in 1991 it is a client driven form of therapy. Designed to be less confrontational than other therapies. Focusing on the understanding of what initiates change while utilizing a guiding philosophy that Fosters balance of components that are both direct and client-centered. A combination of humanistic treatment and enhanced cognitive behavioral strategies. It is similar to motivational interviewing and Motivational Enhancement Therapy.

Patient is encouraged to develop a negative view of their addiction, with the desire to change the behavior. A motivational therapist does not explicitly advocate change and tends to avoid direct contradicting of their patient, but instead expresses empathy, roles with resistance and supports self efficiency. They consider relapses and addictive behavior are a part of the treatment and this is not considered a step back or of failure to advance in treatment. Often Methadone or a similar program is used in conjunction with Motivational Therapy. Motivational Therapy is highly dependent on the quality of the Therapist.

\section{Holistic approach}

The Holistic approach treats the Whole person not simply the symptoms and disease. Mind and body are integrated and inseparable. Practitioners do more than just identify and treat a specific ailment they look at all aspects of your life and health issues and designed a course of treatment to help you reach your optimum level of wellness. Holistic health is not concerned with the Absence of addiction but with a positive state of being, combined with wisdom, traditions and disciplines of Eastern healing arts with advances of modern Western medicine.

Individuals have the responsibility for his/her own health and must be an active participant in their healing. While striving for balance that reflects good health. True healing focuses not just on the treatment of the symptoms but on the underline root causes of and balance in one's life and the disease.

\section{Smart recovery}

The philosophy is that each individual finds his own path to recovery. The path that may include AA/NA or other self empowering groups such as Women for Sobriety, Life Ring Secular Recovery, Moderation Management, or Secular
Organizations for Sobriety. Although smart recovery approaches differs from each of these approaches in various ways, it does not necessarily exclude them.

\section{Religious approach}

Foster's change through the teachings of the Bible. A very strict regimen of following the Bible. One-on-One Counseling Approach Working with a Therapist Who Understands Addiction Primarily a Licensed or Certified Drug and Alcohol Counselor and not just Therapy. Those who stop on their own these individuals have much Insight to offer us on the How?

Dr. Carl Jung believed that the alcoholic/addict suffered from an in completeness, and is on a spiritual quest for wholeness. Addicted individuals are perfect at the skill of self-detachment by rising above or below the conscious self, never having to second-guess when making difficult decisions because self was never a part of the decision making process to begin.

You can't solve a problem from the same level of consciousness that created the problem-Albert Einstein Recovery the bridge that touches both banks when things are not as they should be change is required. Your eyes are the gateway to your soul. One who seeks knowledge understands that knowledge is power peace can only come to looking at the inner self. The purpose of our life is to grow. Recovery is the bridge for the seeker of the other shore in which a new life can begin-David E. McCauley

\section{Addiction to Recovery/Unlocking your Potential}

In recovery, anyone who earnestly applies the principles and methods of change and growth can attain personal fulfillment by unlocking your potential. With continued vigilance, one can maintain recovery for life, understanding that we have the ability to control our impulses and move forward. Perfection in recovery means that one is always working on never allowing any impulses to manifest into addictive or destructive behavior. The power of recovery is in one's life it contains a power that goes beyond words. It can lead us to a much better place, peaceful, and quieter place beyond our thoughts and dreams. A place where serenity can flourish in our thoughts and created problems are dissolved.

You will discover what it means to be creative and be liberated in your life. When I talk about recovery, I talk about a profound transformation that must occur in one's awareness and consciousness for a new personal future. This is achievable for anyone no matter who you are, where you have been, or where you are. This secret to a lifetime of sobriety is maintaining the mind, body, soul, and self, thus staying healthy mentally, emotionally, spiritually and physically as we need to stay one step ahead, always keeping hope alive within us.

The book addiction to Recovery/Unlocking your Potential is an accumulation of existential realization, many resources, 
years of recovery, education, and years working in the field of addiction, with all adepts in the goal of personal transformation from addiction to recovery. This is an integrative approach to living in wellness of recovery.
This work is licensed under Creative

Commons Attribution 4.0 Licens

DOI: 10.19080/GJIDD.2017.02.555577
Your next submission with Juniper Publishers will reach you the below assets

- Quality Editorial service

- Swift Peer Review

- Reprints availability

- E-prints Service

- Manuscript Podcast for convenient understanding

- Global attainment for your research

- Manuscript accessibility in different formats

( Pdf, E-pub, Full Text, Audio)

- Unceasing customer service

Track the below URL for one-step submission https://juniperpublishers.com/online-submission.php 